\title{
A Study on Hidden Curriculum of Ability Grouping Instruction in College English Classes
}

\author{
Su-Lien Liao \\ Department of Applied Foreign Languages, Chienkuo Technology University, \\ $\mathrm{Ph}$. D. student, Department of Education, National Taichung University of Education \\ Taichung, Taiwan \\ suzanneliao@hotmail.com
}

\begin{abstract}
A lot of colleges in Taiwan apply ability grouping on English instruction owing to the poor English of vocational college students, the huge differences of their English ability, and the large classes in English instruction. Previous studies on ability grouping instruction focus on the analysis of the motivation of students in different groups and the efficiency of ability grouping instruction. This paper aims to investigate ability grouping instruction in college English classes from the perspectives of hidden curriculum. Questionnaires and interviews are used to collect the date about students' opinions, experiences, and satisfaction about ability grouping instructions. The purposes of this study is to find out the positive and negative hidden curriculum of ability grouping, to offer the findings to teachers for a more successful practice of English teaching.
\end{abstract}

Keywords- hidden curriculum, ability grouping, English teaching

\section{INTRODUCTION}

In order to improve college students' English ability, Ministry of Education suggested that each college may set up the graduation benchmark for English proficiency. Students must achieve the criteria before they graduate. Tsai and Lin point out the changes of English education in Taiwan's college [1]. Students' English proficiency becomes an indicator used to determine not only if the school education is successful but also the amounts of funds the school can get form the government. In order to perform well, most colleges set the graduation benchmark for English. Liauh indicates that the graduation benchmark for English proficiency is used to measure if students have the English proficiency requested by the school authority [2].

Owing to the poor English of vocational college students, the huge differences of their English ability, and the large classes in English instruction, most college adopt the ability grouping in English instruction to overcome the difficulties in English education and to improve student's learning efficiency. According to the date collected from the colleges' websites in June 2012, thirty-eight private colleges out of sixty apply ability grouping in English instruction in Taiwan. Previous studies on ability grouping instruction focus on the analysis of the efficiency of ability grouping instruction. However, besides formal curriculum, there are informal curriculum and hidden curriculum in school education. Chen proposed that hidden curriculum is in all curriculum and instruction and it influences student's affection and attitude [3]. According to Jakoborits, affective factors, such as needs, motivations, attitudes are the key factors to affect the efficiency of language learning [4]. Therefore, this paper aims to investigate ability grouping instruction in college English classes from the perspectives of hidden curriculum. Questionnaires and interviews are used to collect the date about students' opinions, experience, and satisfaction about ability grouping instructions.

The rest of this article is organized as follows. Section II reviews the theory of hidden curriculum. Section III describes the methods and instruments employed in the study. Section IV presents the results and the finding from the study. Section V provides a summary of conclusions.

\section{LITERATURE REVIEW}

The term "hidden curriculum" was first proposed by Philip Jackson in 1968. He argued that education is a socialization process. He indicated the three characteristics of school life. They are crowd, praise and teachers' authority. Students must learn how to become a group member, how to accept blames and praises calmly and confidently and how to survive in an authoritarian environment [5]. A hidden curriculum is an informal leaning, a side effect of an education. It is what the students learn, such as norms, beliefs, values, through instruction, interaction with the authority and others.

Lin suggests that learning environment affects students' learning experiences a lot. Learning environment includes material, social and cultural environment. The equipments, space allocation in school are parts of material environment. Social environment covers the way of grouping, school regulations, and the relationship among peers or teachers and students. Cultural environment includes the cultural of class or school, activities, and ceremonies [6].

Although hidden curriculum is not included in formal curriculum, it has greater influence on the socialization of students then formal one. There could be positive and negative hidden curriculum. This paper aims to investigate ability grouping instruction in college English classes from 
the perspectives of hidden curriculum, to understand students' opinions, experiences, and satisfaction about ability grouping instructions. The purposes of this study is to find out the positive and negative hidden curriculum of ability grouping, to offer the findings to teachers for a more successful practice of English teaching.

\section{METHODS}

\section{A. Participants}

The participants of this study were freshmen in Chienkuo Technology University in Changhua, Taiwan in 2012. Ability grouping instruction was applied in the English classes at this school. All freshmen took a placement test at orientation meeting and then they were divided into thirty classes and three groups according to the results of the test. Group A is composed by high-achievers while Group C is composed by low-achievers. Stratified sampling was conducted in this study to pick up a class from each group. In total, 146 students took part in the study. In t53.8nd of the school year (May, 2013), a questionnaire was given to all participants in English class. All the students had to hand in the questionnaire but they participants were free to decide if they would like to do the survey, in other words, they can leave the questionnaire as it is. Finally, there were 112 valid samples for this study.

\section{B. Instruments}

1) Interview: Informal interviews were undertaken during the whole school year in order to understand students' affection and opinions about ability grouping instruction in English classes.

2) Questionnaire: In order to identify students' responses to ability grouping instruction, Yu's and Tsai's questionnaires were referred to [7-8]. Five students did the pilot test and three experiences teacher reviewed the draft of the questionnaire. The final version of the questionnaire was divided into three parts.

a) Background: The group and department in which the participant was.

b) Opinions: Five questions were designed to investigate the participants' opioions about ability grouping instruction in English classes.

c) Affection: Five questions were designed to identify the influences which ability grouping instruction had on students' learning motivation and affections.

\section{RESUlts AND DisCUSSION}

\section{A. Valid sample rates}

Table I shows the valid sample rates vary from group to group. Almost $40 \%$ if the students in Group C do not want express their opinions on ability grouping instruction.

TABLE I. A COMPARISON OF VALID SAMPLE RATES

\begin{tabular}{|l|c|c|c|c|}
\hline & Group A & Group B & Group C & Total \\
\hline Samples & 53 & 50 & 43 & 146 \\
\hline Valid Samples & 46 & 40 & 26 & 112 \\
\hline Valid Sample Rate & $86.8 \%$ & $80 \%$ & $60.5 \%$ & $76.7 \%$ \\
\hline
\end{tabular}

What makes them silent? Being the so-called "lowachievers", do they have chances to express themselves in class or at school? In the informal interviews, most of the students in Group C say that they do not like the labeling of ability grouping. The teaching material in Group $C$ is quite easy; therefore, their English proficiency remains the same. School offers very little remedial teaching for them. Most of the English teachers of Groups $\mathrm{C}$ are part-time teachers. They are not so familiar with school's regulations or graduation benchmark for English. They think the school has given them up.

\section{B. Students' opioions on ability grouping instruction in English classes}

TABLE II. A COMPARISON OF STUDENTS’ OPINIONS ON ABILITY GROUPING

\begin{tabular}{|c|c|c|c|c|c|c|}
\hline Question & Group & $\begin{array}{c}\text { Strongly } \\
\text { Agree }\end{array}$ & Agree & Unknown & Disagree & $\begin{array}{l}\text { Strongly } \\
\text { Disagree }\end{array}$ \\
\hline Q1. I am in a group which is suitable to me. & $\begin{array}{l}\text { A } \\
\text { B } \\
\text { C }\end{array}$ & $\begin{array}{c}21.8 \% \\
15.0 \% \\
3.8 \%\end{array}$ & $\begin{array}{l}47.8 \% \\
30.0 \% \\
57.8 \%\end{array}$ & $\begin{array}{l}23.9 \% \\
40.0 \% \\
26.9 \%\end{array}$ & $\begin{array}{c}6.5 \% \\
12.5 \% \\
7.7 \%\end{array}$ & $\begin{array}{c}0 \\
2.5 \% \\
3.8 \%\end{array}$ \\
\hline Q2. The placement test is effective. & $\begin{array}{l}A \\
B \\
C\end{array}$ & $\begin{array}{c}13.0 \% \\
10.0 \% \\
7.7 \%\end{array}$ & $\begin{array}{l}43.5 \% \\
35.0 \% \\
46.1 \%\end{array}$ & $\begin{array}{l}37.0 \% \\
30.0 \% \\
38.5 \%\end{array}$ & $\begin{array}{c}6.5 \% \\
22.5 \% \\
7.7 \%\end{array}$ & $\begin{array}{c}0 \\
2.5 \% \\
0 \\
\end{array}$ \\
\hline $\begin{array}{l}\text { Q3. I do not reject to have English class with students who are not in my } \\
\text { class or department. }\end{array}$ & $\begin{array}{l}\text { A } \\
B \\
C\end{array}$ & $\begin{array}{c}26.1 \% \\
25 \% \\
23.1 \% \\
\end{array}$ & $\begin{array}{l}37.0 \% \\
42.5 \% \\
38.5 \%\end{array}$ & $\begin{array}{l}28.3 \% \\
22.5 \% \\
34.6 \% \\
\end{array}$ & $\begin{array}{c}4.3 \% \\
10.0 \% \\
3.8 \%\end{array}$ & $\begin{array}{c}4.3 \% \\
0 \\
0\end{array}$ \\
\hline $\begin{array}{l}\text { Q4. I think there are more advantages than disadvantages of applying } \\
\text { ability grouping instruction in English classes. }\end{array}$ & $\begin{array}{l}\text { A } \\
B \\
\text { C }\end{array}$ & $\begin{array}{c}15.2 \% \\
17.5 \% \\
0\end{array}$ & $\begin{array}{l}47.8 \% \\
35.0 \% \\
38.5 \%\end{array}$ & $\begin{array}{l}28.3 \% \\
40.0 \% \\
53.8 \%\end{array}$ & $\begin{array}{l}6.5 \% \\
7.5 \% \\
7.7 \%\end{array}$ & $\begin{array}{c}2.2 \% \\
0 \\
0\end{array}$ \\
\hline Q5. I thinking ability grouping instruction is helpful to English learning. & $\begin{array}{l}\text { A } \\
\text { B } \\
\text { C }\end{array}$ & $\begin{array}{c}26.1 \% \\
15.0 \% \\
0\end{array}$ & $\begin{array}{l}36.9 \% \\
35.0 \% \\
50.0 \%\end{array}$ & $\begin{array}{l}28.3 \% \\
40.0 \% \\
42.4 \%\end{array}$ & $\begin{array}{l}6.5 \% \\
7.5 \% \\
3.8 \%\end{array}$ & $\begin{array}{c}2.2 \% \\
0 \\
3.8 \%\end{array}$ \\
\hline
\end{tabular}

As shown in Table II, 69.6\% of the students in Group A and $61.6 \%$ of the students in Group $\mathrm{C}$ strongly agree or agree they are in a group which is suitable to them. $56.5 \%$ of the students in Group A and $53.8 \%$ of the students in Groups C 
strongly agree or agree that the placement test is effective. The opinions of students in Group B on these two questions are a little different from other two groups. $45 \%$ of the students in Group B strongly agree or agree the placement test and ability grouping are effective. $2.5 \%$ of the students in Group B and 3.8\% of the students in Groups strongly disagree they are in a suitable group. The teacher of group $\mathrm{C}$ indicates that some of the students did not take the placement test; they even rejected to take a makeup test or handed in the test paper as it was. Those students are allocated to Group C. Perhaps those are they students who think they are not in a suitable group.

More than $60 \%$ of the students in three groups do not reject to have English classes with students from other classes or departments.
Students' opinions on the advantages and disadvantages of ability grouping are quite different. $63 \%$ of the students in Group A and $52.5 \%$ of students in Group B strongly agree or agree that there are more advantages than disadvantages of applying ability grouping. No one in Group C strongly agrees that. Only $38.5 \%$ of the students in Groups C agree that.

Students' opinions on question 5 are also quite different. $63 \%$ of the students in Group A and $50.0 \%$ of the students in Group B strongly agree or agree that ability grouping instruction is helpful to English learning. No one in Group C strongly agrees that; but $50.0 \%$ of the students in Groups C agree ability grouping instruction is helpful to English learning.

C. The influences ability grouping instruction had on students' learning motivation and affections

TABLE III. A COMPARISON OF ABILITY GROUPING’S INFLUENCES ON STUDENTS’ MOTIVATIONS AND AFFECTIONS

\begin{tabular}{|c|c|c|c|c|c|c|}
\hline Question & Group & $\begin{array}{c}\text { Strongly } \\
\text { Agree }\end{array}$ & Agree & Unknown & Disagree & $\begin{array}{c}\text { Strongly } \\
\text { Disagree }\end{array}$ \\
\hline Q1. Ability grouping instruction increases my interests in learning English. & $\begin{array}{l}A \\
B \\
C\end{array}$ & $\begin{array}{c}4.3 \% \\
10.0 \% \\
11.5 \% \\
\end{array}$ & $\begin{array}{l}45.7 \% \\
20.0 \% \\
30.0 \% \\
\end{array}$ & $\begin{array}{l}47.8 \% \\
57.5 \% \\
50.0 \% \\
\end{array}$ & $\begin{array}{c}2.2 \% \\
10.0 \% \\
11.5 \%\end{array}$ & $\begin{array}{c}0 \\
2.5 \% \\
0\end{array}$ \\
\hline $\begin{array}{l}\text { Q2. Ability grouping instruction enhances my confidence in learning } \\
\text { English. }\end{array}$ & $\begin{array}{l}\text { A } \\
\text { B } \\
\text { C }\end{array}$ & $\begin{array}{c}4.3 \% \\
12.5 \% \\
11.5 \% \\
\end{array}$ & $\begin{array}{l}34.8 \% \\
25.0 \% \\
34.6 \% \\
\end{array}$ & $\begin{array}{l}50.0 \% \\
50.0 \% \\
42.4 \% \\
\end{array}$ & $\begin{array}{l}10.9 \% \\
10.0 \% \\
11.5 \%\end{array}$ & $\begin{array}{c}0 \\
2.5 \% \\
0\end{array}$ \\
\hline $\begin{array}{l}\text { Q3. Ability grouping instruction reduces my pressure and anxiety in } \\
\text { learning English. }\end{array}$ & $\begin{array}{l}\text { A } \\
\text { B } \\
\text { C }\end{array}$ & $\begin{array}{c}4.3 \% \\
17.5 \% \\
15.4 \% \\
\end{array}$ & $\begin{array}{l}28.3 \% \\
30.0 \% \\
23.1 \% \\
\end{array}$ & $\begin{array}{l}50.0 \% \\
42.5 \% \\
57.7 \% \\
\end{array}$ & $\begin{array}{c}17.4 \% \\
7.5 \% \\
3.8 \%\end{array}$ & $\begin{array}{c}0 \\
2.5 \% \\
0\end{array}$ \\
\hline Q4. Ability grouping instruction makes English classes more interesting. & $\begin{array}{l}\text { A } \\
\text { B } \\
\text { C }\end{array}$ & $\begin{array}{c}6.5 \% \\
12.5 \% \\
19.2 \% \\
\end{array}$ & $\begin{array}{l}17.4 \% \\
20.0 \% \\
15.4 \% \\
\end{array}$ & $\begin{array}{l}63.0 \% \\
52.5 \% \\
46.2 \% \\
\end{array}$ & $\begin{array}{l}13.1 \% \\
12.5 \% \\
19.2 \%\end{array}$ & $\begin{array}{c}0 \\
2.5 \% \\
0\end{array}$ \\
\hline Q5. Ability grouping instruction increases my learning motivation. & $\begin{array}{l}\text { A } \\
\text { B } \\
\text { C }\end{array}$ & $\begin{array}{l}8.7 \% \\
7.5 \% \\
7.7 \%\end{array}$ & $\begin{array}{l}21.7 \% \\
30.0 \% \\
34.6 \%\end{array}$ & $\begin{array}{l}54.3 \% \\
45.0 \% \\
38.5 \%\end{array}$ & $\begin{array}{l}13.1 \% \\
15.0 \% \\
19.2 \%\end{array}$ & $\begin{array}{c}2.2 \% \\
2.5 \% \\
0\end{array}$ \\
\hline
\end{tabular}

As shown in Table III, $49.0 \%$ of the students in Group A and $41.5 \%$ of the students in Group C strongly agree or agree that ability grouping instruction increases their interest in learning English. Fewer students (30\%) in Group B have the same opinions.

39.1\% of the students in Group A, 37.5\% of the students in Group B and $46.1 \%$ of the students in Groups C strongly agree or agree that the ability grouping instruction enhances their confident in learning English. 32.6\% of the students in Group A, 37.5\% of the students in Group B and 38.5\% of the students in Groups C strongly agree or agree that the ability grouping instruction reduces the pressure and anxiety in learning English. 17.4\% of the students in Group A think that ability grouping instruction increases their anxiety and pressure.

The opinions of students in Group A on question 4 are a little different from other two groups. $32.5 \%$ of the students in Group B and 34.6\% of students in Group C, but only $23.9 \%$ of the students in Group A strongly agree or agree that ability grouping instruction makes English classes more interesting. Perhaps the school authority and teacher expect more of the students in Group A. The expectation from teachers and other students increase their pressure and anxiety. During the interview, the students in Group A say that they improve their English proficiency a lot in ability grouping instruction. Most of them passed the English proficiency test and achieve school's graduation benchmark for English during the year. They think ability grouping instruction is good for them to improve their English in a short time, but it is not fun. They spent a lot of time practicing and preparing for English tests.

Students have different opinions on whether ability grouping instruction can increase their learning motivation or not. 30.4\% of the students in Group A, 37.5\% of the students in Group B and $42.3 \%$ of students in Group C strongly agree or agree that ability grouping instruction increases their learning motivation. But $2.5 \%$ of the students in Group A and Group B strongly disagree with that statement.

\section{CONCLUSION}

Owing to the poor English of vocational college students, the huge differences of their English ability, and the large classes in English instruction, most colleges in Taiwan apply ability grouping on English instruction. Previous studies indicate that it is effective to improve students' English proficiency. This study compares the opinions and affective factors among the three groups of students. Students in Group A bear more pressure and anxiety than other students. 
They also fear of being evaluated as poor ones compared with what they are expected. Students in Group C do not like the labeling of ability grouping, they do not like being recognized as low-achievers, they hate being given up by teachers and school. In fact, a warm atmosphere is important in language learning. Teachers should be empathic for all the students and create a classroom that every student feels accepted and understood.

\section{REFERENCES}

[1] S. N. Tasi, and C. H. Lin, "The Analysis of English Ability and Proficiency Test for College Freshmen -A Case Study for I-Shou University,” Journal of Humanities and Social Science, vol. 2, no. 7, pp. 29-42, January 2011.

[2] Y. H. Liauh, "A Preliminary Study of Students' Attitudes toward the Exit English Examination in Technological and Vocational Higher Education in Taiwan,” Journal of National Huwei University of Science \& Technology, vol. 29, no. 3, pp. 41-60, September 2010.
[3] B. Z. Chen, A Study on Hidden Curriculum, Taipei: Wu-Nan, 1985.

[4] L. Jakoborits, Foreign Language Learning: A Psycholinguistic Analysis of the Issue. Rowlwy, MA: Newbury House Publishers, 1970

[5] P. W. Jackson, Life in Classroom, NewYork: Teacher College Press, 1990.

[6] S. C. Lin, "The Investigation of the Hidden Curriculum: Taking a Privately Managed Public School as an Example,” Journal of Research in Education Sciences, vol. 54, no. 1, pp. 179-208, September 2009.

[7] C. F. Yu, "A Study on the Freshman English Remedial Program That Employs Blended-Teaching/Learning, " Soochow Journal of Foreign Languages and Literatures. vol.26, pp. 1-29, March 2008.

[8] C. C. Tsai, "The Outcomes and Implementation of the Ability Grouping Program of Freshman English at the National Kaohsiung Marine University,” Journal of National Kaohsiung Marine University, vol. 22, pp.169-184, February 2008. 